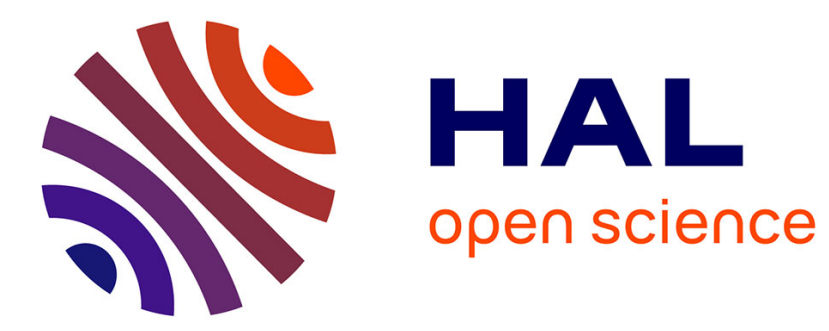

\title{
Luxury stores as home-like places: How domestic meanings are staged and mobilized in luxury retail
}

\author{
Alain Debenedetti
}

\section{To cite this version:}

Alain Debenedetti. Luxury stores as home-like places: How domestic meanings are staged and mobilized in luxury retail. Journal of Business Research, 2021, 129, pp.304-313. hal-03171771

\section{HAL Id: hal-03171771 \\ https://hal.science/hal-03171771}

Submitted on 17 Mar 2021

HAL is a multi-disciplinary open access archive for the deposit and dissemination of scientific research documents, whether they are published or not. The documents may come from teaching and research institutions in France or abroad, or from public or private research centers.
L'archive ouverte pluridisciplinaire HAL, est destinée au dépôt et à la diffusion de documents scientifiques de niveau recherche, publiés ou non, émanant des établissements d'enseignement et de recherche français ou étrangers, des laboratoires publics ou privés. 


\title{
Luxury stores as home-like places: How domestic meanings are staged and mobilized in luxury retail
}

\author{
Alain Debenedetti, \\ Université Gustave Eiffel, Institut de Recherche en Gestion (IRG) \\ Published article available upon request: alain.debenedetti@univ-eiffel.fr
}

\begin{abstract}
While prior studies have examined the creative and sacred aspects of luxury brands, homelike aspects of retail remain under-investigated and under-theorized. Yet this issue is central because in-store domestic experiences can entail strong forms of customer engagement and loyalty. Drawing from observations in luxury stores in Paris, this study demonstrates that domestic meanings are a pervasive element of the luxury in-store narrative that complements the portfolio of meanings luxury brands already use to support their high-end positioning. More specifically, this research shows to what extent and how luxury stores instill home-like socio-material cues that fit with the luxury context in which they are embedded. In doing so, this study contributes to the literature on luxury retail by examining how homeyness is staged in high-end environments, thus complementing prior research on luxury houses as creative and sacred institutions.
\end{abstract}

Keywords: Homeyness, Domestic meanings, Luxury retail, In-store experiences, Place meanings, Observation methods 
Luxury brands have grown accustomed to presenting a monologue about themselves in stores that feel like temples. Increasingly, they will need to transform stores into places that feel like home, delivering distinctive, immersive experiences and engaging in a genuine dialogue with customers (Bain \& Company, 2018).

\section{Introduction}

The market for personal luxury goods has been growing steadily for the past two decades, with an average growth of 6\% a year between 1996 and 2018 (Bain \& Company, 2018). The acceleration of online shopping, pop-up stores, secondhand markets, and luxury rental services has contributed to this growth and made luxury brands more accessible to a new clientele, thus participating in the democratization of luxury brands and changes within the business (Dion \& Borraz, 2017). Traditional luxury brand stores, however, have continued to expand; for example, Louis Vuitton's retail network increased 5\% in fashion and leather goods (1852 stores) and 6\% in jewelry and watchmaking (428 points of sales) in 2018 (LVMH, 2018). This expansion of the distribution network stresses the importance of physical stores in communicating the meanings of luxury brands (e.g., Joy et al., 2014) and the world in which they are embedded (Welté \& Ochs, 2015). Luxury is a way to signal one's wealth to others, and it benefits from the prestige associated with the possession of quality goods sold at high prices (e.g., Ko et al., 2019). It is a medium of self-expression, through processes of affiliation and differentiation (e.g., Chandon et al., 2016; Roux et al., 2017). Luxury also entails emotions, sensations, and dreams (e.g., Dion \& Arnould, 2011). However, as documented in recent research, the understandings (Chandon et al., 2016) and meanings (Thomsen et al., 2020) of luxury are undergoing profound changes. For example, Ko et al. (2016) note that luxury habits shift from possessing a unique and expensive object to experiencing moments of gratification associated with a brand. 
Consistent with research on the transformation of the luxury industry, the introductory quote from Bain \& Company (2018) indicates that luxury brands are facing challenges that may affect how they build consumers' in-store experiences. Prior research has shown that luxury brand stores offer extraordinary experiences to consumers. For example, commercial settings become art institutions providing consumers with elegant interior designs produced in collaboration with renowned artists (Joy et al., 2014), temples where brand rituals are staged (Cervellon \& Coudriet, 2013), places where the magic and artistic ideologies of their creative directors are celebrated (Dion \& Arnould, 2011), or places sacralizing brand heritage (Dion \& Borraz, 2015).

While those studies examine the creative and sacred aspects of luxury brands, home-like aspects of retail are under-investigated and under-theorized, which is paradoxical and problematic. It is paradoxical because, for decades, luxury brands have been describing themselves as "luxury houses," a term that is imbued with domestic meanings. The recent evolution of luxury retail makes the reference to homeyness (i.e., the home-like aspects of a focal place; McCracken, 1989) more visible; for example, pop-up stores implement different aspects of luxury brands' identity, adding to the mythical aspects of the brands' features, such as informality or friendliness (de Lassus \& Freire, 2014), that usually characterize third places or "homes away from home" (Oldenburg, 1999, p. ix) rather than places where social stratification and distinction are primarily managed (Dion \& Borraz, 2017). The relative absence of research on domestic meanings in the luxury sector is therefore surprising, all the more so because homeyness is part of consumers' experience in high-end retail contexts, such as premium accommodation (e.g., Bardhi \& Askegaard, 2009). This under-theorization is also problematic because in-store domestic experiences entail behaviors that are highly valuable from a retailer standpoint. In particular, home-like experiences contribute to building and maintaining strong emotional relationships with the place, such as attachment (Debenedetti et 
al., 2014) and ultimate loyalty (Rosenbaum, 2006), which in turn result in a strong customer commitment. For example, attached customers are eager to participate in the life of the commercial space (Bonnemaizon et al., 2016), to protect it, and to promote it intensely and effectively (Debenedetti et al., 2014). Not taking the managerial benefits of homeyness into account and failing to recognize that domestic meanings manifest in specific ways within high-end contexts can therefore be detrimental to luxury houses.

My research question therefore is: to what extent and how is homeyness staged and mobilized in luxury retail? Drawing from observations in 56 luxury stores in Paris and complemented by informal interactions with store personnel, I show that domestic meanings are a pervasive element of the luxury in-store narrative and play a role in the management of luxury brands, thus complementing the portfolio of meanings already investigated in the literature, including art, magic, heritage, and sacred. By examining the orchestration of homeyness through socio-material cues in this high-end context, this study contributes to the literature on luxury retail by complementing prior research on luxury houses as creative and sacred institutions.

\section{Theoretical background}

Retail spaces are loci for brand meanings. In luxury research, scholars have paid particular attention to art and aesthetics as vessels of meanings and differentiation of brands at their points of sales (e.g., Joy et al., 2014), whereas in social sciences and, more recently, in consumer research, studies have examined customers' experience of homeyness in "local" commercial contexts, emphasizing social relationships (e.g., Debenedetti et al., 2014). In this study, I attempt to combine these different streams of research. First, I examine the extent to which and how home-like meanings are present in research on luxury retail; second, I show the contexts in which homeyness is used in studies on consumer relationships with commercial settings. 


\subsection{The retail of luxury brands}

Scholars have paid particular attention to the way firms have integrated luxury meanings and standards into their luxury brand strategies and then implemented them in stores (Welté \& Ochs, 2015). Flagship stores have particularly been in the spotlight, as they are, beyond points of sales, powerful communication tools for luxury brands (Moore et al., 2010) in which brands' storytelling is staged and emphasized and brands can display dreams, fascination, and distinction by inviting "the clients to absorb some of the magic of luxury creation" (Dion \& Arnould, 2011, p. 513). These studies define stores as cathedrals (Bastien \& Kapferer, 2012) or temples where rituals are staged (Cervellon \& Coudriet, 2013) to sacralize brands (Dion \& Borraz, 2015). In such stores, experience and layouts are crafted to align with the values of luxury. For example, social distinction can be emphasized in the store by managing customers' access to specific areas (Dion \& Borraz, 2017), whereas emotional experiences, such as aesthetic ones, are established through the display of products such as (and among) works of art (Joy et al., 2014).

Common to all these studies is the depiction of luxury brands as more than simply marketoriented. Brands ostensibly suggest their connection with concurrent worlds, which they stage through specific architectural layouts, product displays, and furniture (Joy et al., 2014; Kapferer, 2014) suggesting exclusiveness and pleasure. Reference to aesthetics and art as a central meaning of luxury is particularly salient. Joy et al. (2014), in the case of Louis Vuitton flagship stores, show how luxury brands - for example, by mixing works of art and objects for sale or using displays and spatial elements made in collaboration with artists - blur the boundaries between art galleries and exclusive luxury commercial settings, transforming them into hybrid institutions and reinforcing their aspirational role through an "artistic" experience of which the customer is part. Using a strategic lens, Vukadin et al. (2016) suggest that such institutions are likely to be viewed as less mercantile, but they also note the risk of mixing 
art/aesthetics and luxury: being viewed as a museum does not favor purchase. In their study on the alliance between Louis Vuitton and Japanese artist Murakami, Riot et al. (2013) suggest that working with an artist gives a brand the opportunity to launch new products, but also to revisit the visual merchandising of the place and the store display. Using art at different levels of the value chain contributes to a decommodification of the brand. For example, the customization by Murakami in Louis Vuitton boutiques with new monograms radically changed the ceremonial aspects of and instilled more playfulness in the store atmosphere. Dion and Arnould (2011), for example, demonstrate that the de-marketization of luxury brands is not only a matter of external affiliation; the "artification" of a luxury brand can also be based on internal assets. Dion and Arnould emphasize the role of the artistic director in building an aesthetic brand ideology to differentiate and manage brand success. They note that "a logic of adoration which has a charismatic basis" (p. 503) is implemented in stores, for example, through screens showing fashion shows or windows containing showpieces serving as evidence of the creative power and artistic authority of the artistic director. In summary, research depicts the luxury store as a sacred, distant, and impressive environment similar to a museum but that also favors dreams and pleasure (e.g., Joy et al., 2014).

By contrast, the domestic meanings in luxury retail have been under-theorized-even questioned (Dion \& Borraz, 2015) - in research on luxury retail, though prior research provides hints of home-like cues in luxury stores. For example, examining the motivation of luxury buyers in pop-up stores, de Lassus and Freire (2014) show how characteristics of these small venues make the experience intimate, friendly, and protective, resulting in a cocooning effect. In their investigation of appropriation of luxury stores, Welté and Ochs (2015) explain how regular customers feel at home from the informality and conviviality provided by familiar salespeople. Yet domestic aspects are not regarded as core elements of luxury retail, 
though a growing body of research (e.g., Debenedetti et al., 2014; Rosenbaum, 2006; UlverSneistrup \& Johansson, 2012) suggests that consumers can feel at home in a variety of commercial settings and that this feeling may lead them to develop strong attitudes and behaviors toward their cherished commercial environments.

\subsection{Domestic meanings and homeyness in consumption studies and research on retail environments.}

More than 30 years ago, McCracken (1989) coined the term "homeyness" to describe the constellation of meanings and goods symbolizing the home in North America and divided it into physical, pragmatic, and symbolic meanings. Symbolic domestic meanings are the core of McCracken's approach, in which homeyness (or homeliness: Dion \& Borraz, 2015) refers to a set of home-like properties of a place embedded in a sociocultural context. In particular, McCracken defined home-like spaces as diminutive (small and, therefore, graspable), variable (non-linear and, therefore, not uniformly reproductible), embracing (intimate), engaging (warm and inviting to interaction), mnemonic (localized in time), authentic (real and, therefore, untouched by market calculation), and informal (and, therefore, secure), all properties allowing inhabitants to feel part of them (situating property).

Although research on homeyness often takes place in the context of residential settings, "home is much more than a living accommodation" (Sixsmith, 1986, p. 292): feeling at home can occur when people transform a neutral space into a place providing meaning and emotions (Manzo, 2003). For example, Seeley et al.'s (1956) study on high society shows that Crestwood Heights (a suburb of Toronto) dwellers found their club homier than their home, where decorations and furniture were prescribed by home designers and offered no possibility of modification and personalization. Prior research also shows that domestic meanings extend to commercialized places that are meaningful to a community. For example, Charleston 
(2009) finds that English professional football home stadiums benefit from some qualities of a home (i.e., feelings of belongingness, continuity, or ownership), provide social interaction, and foster place attachment. Comparable benefits are also present in what Oldenburg (1999) calls "third places," or spaces that provide patrons with informal social interactions outside the home and workplace. Oldenburg's study puts emphasis on local commercial places, such as pubs, hair salons, and bookstores, and their role in building and maintaining social connections at a local community level.

In marketing, and more specifically in literature on retail experiences, studies have examined homeyness in different cultural contexts and categories of commercial settings, such as U.S. diners (Rosenbaum et al., 2007), Swedish grocery stores (Ulver-Sneistrup \& Johansson, 2012), and French wine bars (Debenedetti et al., 2014), showing that the experience of being at home is often associated with place attachment and related concepts such as loyalty (Rosenbaum, 2006). This feeling of being at home leads consumers to engage in highly valuable behaviors from a retailer perspective: consumers over-reciprocate to the commercial setting (Debenedetti et al., 2014; Price \& Arnould, 1999; Rosenbaum et al., 2007), for example, by giving waiters disproportionate tips; they are eager to participate on the spot in back-office activities (Bonnemaizon et al., 2016); or they serve as ambassadors for the place, for example, by engaging in "selective matchmaking" (Debenedetti et al., 2014, p. 915), which involves bringing deliberately chosen friends and relatives to the home-like place. In summary, when deemed homey, a commercial environment contributes to build strong forms of bonding with consumers and can differentiate itself from competitors.

Although home-like elements are present in retail, research is limited to rather local and independent commercial environments in which home-like feelings primarily rest on genuine and sincere social interactions (with the manager, the staff, or the consumer's extended social network) (e.g., Rosenbaum, 2006) and, to a lesser extent, on material elements. For example, 
home-like aesthetics are unpretentious and, more important, decommercialized: this means that the material aspect of homeyness is strongly associated with its social aspect, as homelike decorations or furniture reflect the owners' personality (Debenedetti et al., 2014). In addition, the question of how homeyness is managed is scarce. An exception is Alexander (2019), who examines the third-place qualities of fashion stores from a consumer perspective. She identifies the extent to which different forms of third places (cafés, barbers, workshop) are included in fashion stores, especially in mid-range and luxury ones. She suggests that these spaces within a space offer social and restorative experiences but are also rarely capable of triggering "place-as-home" experiences. However, although new retail formats or commercial devices favoring intimacy and at-homeness seem to develop in the luxury sector, to my knowledge, no research has examined the extent to which—and how-domestic meanings are staged and mobilized in this context, even though luxury stores "allow for surprises and delight, along with feelings of being soothed, and even being 'at home"” (Joy et al., 2014, p. 357). My aim therefore is to show how luxury retail stores instill specific homelike cues by building on socio-material elements that then lead to domestic meanings aligned with the luxury context in which they are embedded.

\section{Method}

\subsection{Research context}

To explore homeyness in luxury commercial environments, I focused on Parisian stores, as Paris has a long history in luxury retail. In 1770, for example, Rose Bertin, known as the "ministry of fashion" of Marie-Antoinette, opened her store on rue Saint-Honoré, located in a fancy neighborhood that had already attracted reputed cosmetics stores. Almost a century later, Le Bon Marché (in 1852) paved the way for multi-category/multi-brand high-end retail environments by becoming the first "modern" department store of the world. Last, with the 
emergence and institutionalization of Haute Couture in 1911, fashion shows began to take place in fancy salons, that is, in between wealthy flats and luxury commercial environments in which collections were presented to rich customers. Luxury brands also have a specific relationship to home meanings, as evidenced in their French name maisons de luxe (i.e., luxury houses). This term began being used in the luxury sector in the late $19^{\text {th }}$ century (Annuaire-Almanach du Commerce de Didot-Bottin, 1888). More so, in French, the word "maison" refers to both the house (i.e., the spatial aspect of a dwelling) and the home (i.e., the symbolic aspect).

\subsection{Data collection and analysis}

Because the empirical study is exploratory and aims to understand how luxury stores stage the domestic dimension, I employed a qualitative method based on observations (Borghini et al., 2009; Dion \& Borraz, 2017). The research site is a set of Parisian luxury stores. I selected stores using the following criteria: they operated in different sectors, were of different sizes, and were located in Parisian luxury neighborhoods (e.g., Triangle d'Or, rue Saint-Honoré, Boulevard Saint-Germain, Marais area). I first observed 84 luxury retail environments at different moments of the day/week and identified whether there were hints of homeyness. On that basis, I eliminated 28 stores where domestic meanings were marginal and finally spent 20 to 90 minutes (for a single visit) in each of the 56 remaining stores, depending on its size, complexity, and social interactions with sales personnel (see Appendix 1 for the final list of stores). Data collection stopped when I reached theoretical saturation (i.e., when visits no longer resulted in new information).

Visits were conducted by me and trained assistants. For each visit, field notes were taken and included personal diaries, structured notes, pre-analysis, and theoretical references and were accompanied by photos when possible. Though primarily based on non-participation 
observation, these data were combined with informal chats with store personnel, going back and forth between covert (researcher as a pseudo customer) and overt (researcher engaging an "expert" conversation with sales personnel) observation, to obtain different forms of discourse (customer-oriented vs. reflexive and strategic). The initiative of an informal interaction was left to store personnel as hosts. The research method constitutes a quasi-ethnographic approach, as I aimed to discover "how things work" (Watson, 2011, p. 202) in a collection of stores.

I began analyzing the data during data collection, engaging in multiple iterations between data and the emerging theory (Glaser \& Strauss, 1967) and examining the data using different conceptual frames on home/homeyness, ranging from environmental psychology to architecture and sociology. A systematic observation, semi-open grid was used. It was constructed after the first round of non-structured observation. This form of grid focuses on the key elements of the commercial environment while facilitating the inclusion of unexpected elements (Dion \& Arnould, 2011).

The initial analysis involved coding for descriptive elements related to the key constituents identified in the store (including the façade and immediate surroundings). Subsequent analyses focused on the relevant themes for describing a home place: place materiality (e.g., architectural elements, interior design, furniture and decoration), social interactions in the place (e.g., welcome, content of informal chats), and related activity patterns (e.g., salespeople's initiatives) (van der Klis \& Karsten, 2009).

\section{Findings}

Luxury boutiques have a set of architectural, material, and social cues that evoke a home to different extents. The common point of these home-like commercial environments is that 
luxury stores are not just any home: domestic cues I identified suggest that homeyness is strongly imbued with luxury meanings.

\subsection{Luxury stores as private residences}

Home-like places are characterized by embracing surfaces (McCracken, 1989), which enable the spatial environment to provide "security through physical protection against the outside world" (Debenedetti et al., 2014, p. 913). More than commercial settings, whose doors are left open to attract people, private residences are separated from the outside by a succession of layers, thus emphasizing intimacy (McCracken, 1989).

Data show that these layers start with stores being located in "protected" areas, in the highend neighborhoods of the very center of Paris, where luxury stores rub shoulders with historical monuments, museums, ministries, art galleries and high-end hotels. Luxury stores are usually better integrated within the local urban landscape than mass-market commercial environments, because they are located in private mansions or beautiful Haussmann-style buildings. Their doors are usually closed, thus offering no invitation to customers to enter freely, contrary to mass-market stores. This effect is reinforced by the presence of other thresholds: at Boucheron or Bulgari, thresholds materialize with the presence of steps, and many boutiques on the Avenue Montaigne, the heart of the Parisian Golden Triangle, are set back behind a small alley marked by the presence of an ornate gate, whose gilding on the top also signals the exclusiveness of the place. These arrangements downplay the idea of market, as they force customers to expend effort to enter the brand's home: luxury stores command scheduled visits, favored by the development of omni-channel tools such as the e-reservation, rather than improvised shopping. In several stores, such as Moynat, Vacheron-Constantin, and Chanel avenue Montaigne, these thresholds are accompanied by glazed windows that make the interior layout of the boutique not easily visible. While the presence of a doorbell is a means of ensuring the security of the stores, its presence at Goyard or Boucheron, 
accompanied by the notice "ring here," reinforces the idea of going to someone's home. For example, the entrance to the Schiaparelli boutique, referred to by a manager as a "lounge," in reference to the way the designer received her clients in the 1930s, has a door guard located outside the building and (when not available) a standard intercom, in which a customer must search for the brand among a list of names and notify the boutique of the visit, as is the case in everyday life. In addition, the well-dressed door guard resembles a butler meeting the guests at the door of a mansion or a castle.

Thus, a material and symbolic separation exists between the inside and the outside (McCracken, 1989), reinforced by multiple devices sometimes combined. For example, the Antik Batik boutique combines the absence of a shop window with the presence of several high steps, the Baccarat boutique is located at the end of a porch of a mansion house, and the Schiaparelli boutique is on the third floor of an impressive dwelling. This symbolic separation from the outside also means that only the privileged few can easily access the store- it is not always easy to spot and, when it is, does not spontaneously invite people to come in. In summary, the architecture is conceived as a private (vs. a marketized and public) residence but also signals brand status and exclusiveness, which is different from other commercial settings.

\subsection{Luxury stores as intimate and exclusive places}

Within luxury boutiques, the spaces themselves are structured in such a way as to leave aside the commercial aspect. At one visit to the Balmain boutique (rue Saint-Honoré), a salesperson explained how the store has been, as far as possible, structured like a traditional luxury Parisian apartment, in which one room is distinguished from another:

Made by three young designers, [the store] is based on the concept of Parisian private mansions: here you have the library. You enter directly into the library, where you can see 
the shelves with the book part, there, on the right and on the left. After here, you have the games room, there the vestibule.... The parquet comes from a Parisian mansion: we bought the entire wood floor of a huge mansion.... We equip all the shops in the world with this wood floor. So, there you have the vestibule, just before the stairs.... It looks out onto the garden, on the model of the interior gardens that you can find in private mansions, and there, finally, you have the hall of mirrors. (Sales representative at Balmain)

By conceiving the luxury store as an apartment with different rooms, luxury brands also extend symbolic protective layers into the interior of the store. Beyond the dividing walls, decorative elements add to the partitions: walls of the Sonia Rykiel flagship are filled with books, and the stairs of Ralph Lauren's, Paul Smith's, and Tiffany \& Co.'s stores are filled with photos and/or paintings carefully framed and harmoniously hung on the wall. Chanel's flagship store is also dressed with Chinese lacquer folding screens, which, beyond their main function, serve to promote pieces of Gabrielle Chanel's heritage (Dion \& Borraz, 2015) and make the place the "home of a collector" (Joy et al., 2014, p. 353). This abundance of interior separations, staged to make the store beautiful and impressive, also makes it more intimate. Even a flagship store can generate a cocoon effect by integrating small rooms or partitions that reduce the impression of volume. In other words, unlike mass-market stores, luxury commercial settings make gigantism intimate. This "diminutive" effect (McCracken, 1989) allows clients to appropriate the space and isolate themselves (Joy et al., 2014). At Weston's Rue des Archives, the presence of a thick carpet at the foot of a large comfortable sofa allows this appropriation. The store manager explains that customers sit cross-legged on the sofa, stay there after trying on shoes, and walk around the store in socks, all of which are unusual in the brand's other stores, which do not have this decoration. 
It's true we're in a special place. It's the only store we have in this configuration, this decoration. Well, we welcome people as if they were at home. It fits a little bit with the atmosphere of the neighborhood, relaxed.... That's it, that's what makes people feel good, have a good time. And it works: they walk around in their socks, they sit on the sofa in their suits, they feel comfortable, they look good. They stay. Some of them just come in for coffee sometimes. So that's it, that's it, just like at home. We have other shops less accessible, more impressive. (Sales representative, Weston)

The spatial configuration may encourage customers, even in luxury stores, to experience and enjoy unconventional practices. However, intimate rooms like small lounges (e.g., Bulgari), family rooms (e.g., Breitling), or VIP lounges (e.g., Tiffany \& Co), signal both homeyness and distinction within the space, as a sale representative at Boucheron indicates:

There is a 160 square meter flat within the store, with a dining room, a lounge, a bedroom, and a bathroom.... It allows us to invite VIP clients to stay for one or two nights. And this is not something that we charge.

According to environmental sociologists and architects, dwellings include both public and private spaces (Korosec-Serfaty, 1984): public areas are accessible to acquaintances, whereas private ones are reserved to intimate relatives. Once inside the store, the interior design and layouts combine hints of exclusiveness with devices favoring consumers' emotional experiences associated with privacy and intimacy.

\subsection{Luxury stores as an authentic and dream home}

The personal and home-like furniture and decorations, while expressing the opulence of precious woods, marble, and gilding, seem to take precedence over commercial furniture and partially erase the commercial function of the place. Overall, the stores are like idealized 
houses. They are reminiscent of interior design magazines, in which disorder is chic and everyday objects are aesthetically pleasing and/or magnified. Cartier, for example, is replete with "small salons decorated like apartments, with benches, Egyptian statuettes, lithographs of actresses, books on the brand and on aviation, as well as photographs of Santos Dumont, an aviator who used Cartier watches" (field notes). The presence of sofas and coffee tables, on which newspapers, magazines, beautiful books, fresh flowers, knick-knacks, and other objects not intended for sale are placed, put the customer in a liminal universe, between a commercial and a fancy domesticated space. Decoration is not clearly standardized and alludes to collectibles of an art lover, echoing the manager's personal touch through the display of objects in home-like commercial places (Debenedetti et al., 2014). At Vacheron Constantin and Chanel Place Vendôme, vases and sculptures adorn the rooms; at Alexander MacQueen, the dark wooden floor creaks under the footsteps of visitors, reinforcing the impression of authenticity that emanates from the old wood used in many high-end boutiques. At Ralph Lauren, all the rooms are adorned with objects that allude to life in a beautiful New England home, such as tennis rackets or oars:

From the first floor, for example, I felt like a guest of a bourgeois family living here. Several times I settled down in the magnificent armchairs and sofas, imagining that they were going to serve me tea.... Throughout the visit, you can find furniture and elements that could be those in a real home: soft sofas and armchairs facing coffee tables with books, pedestal tables with delicate vases decorated with rich bouquets of flowers, elegant carpets on the floor, galleries of photo frames and paintings on the walls ... but also more unusual objects such as this boat suspended from the ceiling, this stuffed reindeer head, these mountaineer's ropes, these vintage suitcases, or these wooden skis. These elements, as I learned during the visit, are mostly the trophies of Ralph Lauren himself, who attaches 
great importance to the authenticity of the patina of these objects, which all have something to tell (field notes).

Authenticity emanates from the accumulation of objects alluding to tradition, distinction, and relationship to the past (Napoli et al., 2014), whereas social distinction emanates from details of the home-like decoration: sports items allude to elite sports, knick-knacks to contemporary art, and furniture to design and/or designers with historic meanings, all of them referring to social practices alluding to bourgeois life and taste (Bourdieu, 1979) with which only "elected" customers are familiar. In addition, luxury brands show how they are integrated in the neighborhood and in the elite Parisian life. For example, Sonia Rykiel and Louis Vuitton Saint-Germain (before remodeling) reveal their closeness with the artistic and intellectual Paris in their Saint-Germain-des-Prés stores-Sonia Rykiel, with a collection of 50,000 paperback books, and Louis Vuitton, with a room furnished with old dark wood furniture and dedicated to books and writing instruments.

In summary, meticulously arranged and decorated by interior designers, luxury brand stores build on domestic meanings but, at the same time, position themselves as legitimate institutions capable of defining what contemporary design is and thus emphasize the hierarchical nature of their aesthetics tone, as specialized magazines or blogs would do (Arsel \& Bean, 2013). This is reinforced by the role of the artistic director in aesthetic details. A salesperson from the Paul Smith boutique explained, by pointing to a small window, that at each point of sale, objects found by the designer himself contribute to the decoration of the place, thus emphasizing the willingness of luxury brands to communicate about their leadership in defining taste.

\subsection{Luxury stores as the stage of home-like and distinguished social interactions}


Homeyness in luxury boutiques also rests on social elements as, in contrast with massmarket stores, the interaction with staff is more extended and codified. Although many studies show that sales staff in luxury boutiques can contribute to reinforce the feeling of inferiority of customers who feel illegitimate (Dion \& Borraz, 2017) or condescended to (Ward \& Dahl, 2014), data show that physical arrangements involve home-like social interaction. For example, as Debenedetti et al. (2014) find in the case of a restaurant, a closed door or a doorbell implies a personalized welcome, sometimes supported by the use of a domestic semantic, such as "Welcome to our home" (field notes, at Chopard's and Louis Vuitton's). In rare cases, welcoming visitors leads to a short conversation. If welcoming customers is systematic in the stores observed (by door and security guards, salespeople, or managers), the way this unfolds depends on the commercial density and the size of the store. For example, during my first visit to the new Ralph Lauren store, a warm welcome on each floor was the norm. However, when the store is busy, the welcome ritual is shorter, but again, a comparison can be made with the private sphere, in which the time spent by a host with each guest at a small dinner is not the same as at a large party. In addition, the method of welcoming customers is aligned with the luxury positioning: at Breitling, "I immediately felt a more relaxed atmosphere than I had imagined given the neighborhood. The setting was atypical, pleasant and warm.... The elegance of the shop is reinforced by the look and attitude of the staff: welcoming, but with a certain restraint" (field notes). The welcome provided sometimes imitates the idea of being invited into someone's home, though for a rather formal occasion: at Schiaparelli's, "they make me wait in a room decorated like a living room, bringing me a cold drink on a small tray. Very quickly, someone comes to warn me that my 'guide' is coming at any moment" (field notes). At Shang Xia, the "tea ceremony" when interacting with the salesperson around ceramic products reminds customers about the importance of enjoying shared moments with acquaintances. According to Boltanski and Thévenot (2006), the 
welcome rituals are "distinguished," as distinction is one of the central elements of the domestic world.

Social interaction is however not limited to welcome rituals, and a home-like atmosphere is favored by the staff at most boutiques. For example, at Boucheron, the sales representative explains that people should "feel at home" and "quite relaxed": the place strives to be "extremely friendly, warm, nice, but at the same time, always with an elegant and luxury tone." In the store, social interaction is also supported by the material elements that buttress the brand's storytelling. Objects, drawings, photos, and architectural details are elements on which informal discussions can be initiated with customers. Salespeople are no longer like curators presenting works of art in art institutions (Joy et al., 2014); they are hosts and behave as such, distilling anecdotes about the store, as an owner would when providing a tour of his or her home. Home-like social interaction depends on the commercial context but can sometimes be routinized. A manager explains that in the Schiaparelli "salon," a historical narrative of the boutique is systematically provided and lasts approximately 15 minutes - the fashion collection comes afterward. This "guided tour" of the store is a way to interact more informally with customers and can be compared to "Open Days," a time in France when people can access places that are not usually available to the public. During tours, anecdotes subtly mix stories about the place, its history, and related figures (often including the founder and its family), with the focal brand staying in the background: "[during the visit], I have been shown the hidden spaces and doors to escape, well, incidentally to allow men to flee in order not to be seen with their mistresses" (field notes, Boucheron). Again, commercial aspects are downplayed, so that intimacy with customers can be established. With such social interactions, luxury brands involve customers as confidants. By mimicking hosts taking care of their guests in a prestigious historical dwelling, luxury brands favor customers' personal 
pleasure and "social identification with affluent consumers" (Seo \& Buchanan-Oliver, 2019, p. 418).

Material elements such as photos, paintings, or objects directly may also allude to people who played a central role in the brand's history. In addition to depicting the brand's heritage (Dion \& Borraz, 2015) and inscribing it in history, these elements often link the brand to a personal, family history, through the everyday objects of the creator and/or artistic director. In Dior boutiques, freshly cut hydrangeas, Louis XVI chairs, and the use of the color gray allude to Christian Dior's past, but this past is linked to his childhood in the family home in Granville, France. Stores are embodied by a central figure through references to his or her personal belongings: Chinese lacquer folding screens at Chanel rue Cambon is a wink to her apartment, which is located above the store. There is consequently a sort of "social presence," because the place is inhabited by the spirit of the distinguished host behind the brand.

The presence of workshops in luxury stores also refers to a socio-material aspect of traditional home. The visible and accessible craftsman "inhabiting" a store, such as Berluti, gives the store functions other than commercial ones: the craftsman thus serves as much to build a more intimate social interaction around authenticity as to perform a "handmade" task. This provides an extra moment during and after purchase and a new status for the customer, who may feel more as a close friend of the brand. But, in that case, homeyness is more "marketized," as the degree of interaction and intimacy with the craftsman depends on customers' purchase and customization. Again, as in the home, the status of the guest favors his or her appropriation of the place (Rybczynski, 1986). A Louis Vuitton manager explained that the Place Vendome flagship is called a "house" because "there is an atelier where clothes and other made-to-measures products are manufactured." When the presence of a real workshop is not visible, smaller devices (e.g., printings, engravings) help evoke the idea of manufacturing on the spot through customization operations. Through the implementation of 
ateliers, luxury stores do not only encourage personal imagery through the creation of a craftsmanship atmosphere or perfectionism and self-enhancement through the engagement with a high-quality and artisanal product; they also promote customers' co-construction of luxury items, emphasizing the agentic dimension of unconventional luxury (Thomsen et al., 2020).

Home-like meanings rest on a large array of fancy material cues both inside and outside the luxury store. From the entering procedures to the way non-commercial furniture and architecture are displayed, luxury stores favor an intimate, though sometimes intimidating, journey in an aspirational environment, in which aesthetics, materials, suggested practices, and affiliations allude to social distinction and self-accomplishment but also to an experiential environment in which homey luxury means inconspicuousness and the search for private symbolism.

\section{Discussion}

In-store home-like meanings favor the development and maintenance of emotional bonds between customers and commercial places (e.g., Rosenbaum, 2006) and turn consumers into supporters and promoters of these home-like environments (Debenedetti et al., 2014), thus contributing to their survival. This study documents to what extent and how luxury retail stores in Paris stage and mobilize homeyness, by using material and social cues mimicking authentic and idealized private residences, with an intimate and exclusive atmosphere, and home-like and distinguished social interactions. In doing so, this work enriches the conversation on luxury retail beyond that of other types of retail formats, such as pop-up stores (Klein et al., 2016), that provide consumers with more intimate experiences (de Lassus \& Freire, 2014; Lunardo \& Mouangue, 2019). This study shows how in-store domestic meanings are intertwined with social distinction, aspirational living, and self-expression and 
result in a specific form of homeyness: not only do luxury stores take over domestic meanings, but homeyness is also an integral part of luxury values. Finally, following Thomsen et al. (2020), I also emphasize the appropriateness of using qualitative methods to further understand changes in luxury retail.

\subsection{Home-like cues with a luxury meaning}

While prior research shows that the artistic (e.g., Joy et al., 2014), creative (Dion \& Arnould, 2011), and sacred (Dion \& Borraz, 2015) dimensions of luxury are strategically implemented in high-end boutiques by building on multiple cues, the current study suggests that domestic meanings are also staged and mobilized in luxury brand stores through a cornucopia of material and, to a lesser extent, social elements. Although these elements comprise the home sphere (McCracken, 1989), how homeyness is implemented emphasizes the key role of prestige in luxury consumption (Vigneron \& Johnson, 1999) - the store entrance alludes to an exclusive private residence; the interior design imitates a traditional Parisian flat (e.g., moldings, wood floors, mirrors, multiple rooms); the omnipresent homelike furniture (e.g., carpets, coffee tables, couches) is made of noble and expensive materials; the domestic objects (e.g., books, works of art, games, flowers, family portraits, familyrelated possessions) denote an aesthetic pursuit; guests' authentic welcome, customer- (vs. product-) oriented informal chats, and anecdotes about the place and it history are uttered in a distinguished and hushed tone; and separation between spaces open to all guests and spaces reserved for "close friends" subtly indicates social distinction within the store. In other words, homeyness in luxury retail is not a mere addition of domestic cues to already-existing ones, but a consistent alignment of domestic and luxury meanings. Therefore, this study enriches the understanding of a key meaning of luxury retail and illuminates the role of in-store versus online experience in the context of luxury (e.g., Kefi \& Maar, 2018). 
The experience of home is central and universal because of its role in identity construction (Smith, 1994) and its emotional significance in people's everyday lives (Roster et al., 2016). However, home is a complex and contingent notion that depends, for example, on ethnicity or social class (Blunt, 2005). In the luxury world, home-like meanings intersect with the interpersonal values of luxury, in particular social stratification, to distinguish relatives (i.e., VIP/good clients) from simple guests (casual strollers, "new" customers). They also echo personal values of luxury, when homey practices such as handcrafted customization enhance consumers' self-concept or when a master's work of art indulges in personal pleasure. Homeyness in luxury retail is built on a rich combination of socio-material elements that intersect with a large array of traditional and contemporary meanings of high-end living (Thomsen et al., 2020).

\subsection{Reinterpreting homeyness as an important aspect of luxury retail}

Although domestic meanings constitute an essential, though not prominent, aspect of luxury retail, researchers have questioned the presence of homeyness in luxury stores (Dion \& Borraz, 2015), because the contingent aspect of homeyness has been overlooked in the literature. According to Fashion Network (2017), luxury is undergoing changes stemming from consumers "looking for comfort and ease, more than they are looking to show off when they go to luxury stores [and] want to be themselves and not necessarily project an image of opulence in public.” In other words, domestic meanings are now part of an experiential and ephemeral luxury (Thomsen et al., 2020), and are capable of fostering consumers' emotions by fully integrating them into the brand space and history.

This is why luxury brands are increasingly enriching their repertoire of domestic meanings through the integration of home-related concepts, such as familiarity (e.g., Kim et al., 2016) and intimacy (de Lassus \& Freire, 2014), or through new distribution formats (Klein et al., 
2016), such as pop-up stores, in which homeyness is easier to stage through social interaction than in regular luxury stores. This type of store enables luxury brands to go beyond cues of exclusivity and reverence and build on additional elements favoring intimacy or friendliness (de Lassus \& Freire, 2014), which are central to homeyness, as already realized in mundane commercial places such as hair salons (Price \& Arnould, 1999) and restaurants (Debenedetti et al., 2014; Rosenbaum, 2006). With their reduced dimension, easy accessibility, and ability to spark informal discussions between salespeople and non-regular customers, pop-up stores can relieve consumers of their embarrassment or uncertainty when entering luxury stores (Lunardo \& Mouangue, 2019).

Meanings currently attributed to regular luxury stores can also be reinterpreted as hints of domestic meanings. For example, in their study on heritage stores in the context of luxury brands, Dion and Borraz $(2015$, p. 83$)$ note that they "did not notice any feelings of homeyness or familiarity. In contrast, [they] noticed the opposite: behind-the-scenes access is denied except for extraordinary events, access to different areas of the store is controlled, and customers change their behavior when entering the store." However, these characteristics can be interpreted in a different way, as home is also a place where access is controlled, where some areas are not accessible to all (Rybczynski, 1986), and where hospitality norms such as politeness are expected (Boltanski \& Thévenot, 2006). In summary, what is sometimes considered opposed to domestic meanings rather corresponds to the contextualization of homeyness within the luxury world. As Joy et al. (2014) acknowledge in their ethnographic work on luxury flagship stores operating as art institutions, consumers spontaneously compare luxury stores to the home of an art and artifacts collector and even feel at home in spaces they find intimate and comfortable. Their research suggests that, far from being only museums where aesthetics is staged, luxury flagship stores can instill domestic meanings. 
At the brand level, domestic meanings are part of the DNA of many luxury brands. Of the 36 brands studied, ${ }^{1} 25$ use the term "maison" in their online stores to qualify themselves, either on their main page or on secondary pages dedicated to the presentation of the brand. For example, Boucheron's “La Maison/26 place Vendôme” web page explains,

[Frédéric Boucheron] created an art of living, wishing to receive his clients as if they were at home, at the very heart of creation. This is reflected in a special atmosphere where this family spirit is perpetuated and where each generation succeeding Frédéric Boucheron brings its own style and touch. The atmosphere at 26 Place Vendôme is so special that it gives the feeling of being welcomed like a member of the family. ${ }^{2}$

This excerpt, which is in line with in-store observations, shows that using the word "maison" contributes to elevating the word "brand" while emphasizing home-like values, mainly through stories about the founders/artistic directors or families that have played a significant role in the development of the brand.

\subsection{Implications for managers}

Circling back to the Bain \& Company introductory quote, it is clear that luxury brands do not need to transform: domestic cues are already present in their stores, and they represent an opportunity luxury brands should seize. From a managerial perspective, and especially because of the benefits associated with homeyness at the point of sale (Debenedetti et al., 2014), complementing the range of experiences and meanings in luxury stores by implementing appropriately home-like elements fits with the evolution of luxury brands and their clientele: millennials particularly value experiences (Oyedele \& Simpson, 2018) and stories behind the scenes (brands/products) (Baron, 2015). Home-like elements are an

\footnotetext{
${ }^{1}$ Online stores of the brands I studied were checked on May 2, 2020.

$2 \mathrm{https}$ ://us.boucheron.com/en_us/the-maison/26-place-vendome.html.
} 
appropriate vessel for anecdotes about luxury brands and the family environment in which they are embedded, as well as intimate and domestic experiences (e.g., Boucheron store). With tradition, politeness, and distinction being both part of the meanings of luxury brands and the core principles of the domestic world (see Boltanski \& Thévenot, 2006), staging homeyness in luxury brand stores is not difficult, because, as I show herein, exclusive brand stores already contain many domestic cues.

The question is rather how luxury stores can use the available domestic resources (e.g., furniture, objects, rituals, personnel) appropriately and with consistency. This study shows that material home-like cues are prevalent in the luxury sector. Because materiality is more persistent and less heterogeneous than social elements, brands should use home-like architectural elements, furniture, and store paraphernalia to reinforce and, in some cases, even counterbalance the sales staff's ways of interacting: sometimes, interaction is inappropriate and thus can damage the brand image in the long run. The social dimension of homeyness is more complex to implement, as shown by brands' sales personnel sometimes confusing social distinction with disdain, rudeness, and poor or average service quality (for an example, see Ward \& Dahl, 2014). Instead of using gatekeepers as exclusive agents, some brands have proved that they can also create luxury and home-like experiences, even in the case of top luxury brand stores, such as Breitling and Schiaparelli's, in which top luxury goes hand in hand with friendliness toward all guests.

In addition, building on domestic meanings requires consistency. Managers should work to align material and social homey cues to create a fully authentic experience that is central to luxury (Beverland, 2005) and homeyness (Debenedetti et al., 2014). For example, managers could focus on history and heritage (Dion \& Borraz, 2015) with material cues and on family anecdotes and personalized welcome with a genuine social interaction. On the contrary, they should avoid using meanings at odds with the domestic realm, such as queuing or ignoring 
customers (Pine \& Gilmore, 1999). Being authentic also means building on the cultural context of which the store is part. In the Sonia Rykiel flagship store, staging homeyness entails both communicating the history and values of the host and building on the relationships between the store and its neighborhood. Chanel rue des Francs-Bourgeois boutique shows its "integration closeness" (Schultz et al., 2016) by integrating the architectural codes of the historical Le Marais area in which it is located.

This research also suggests that managing domestic meanings depends on commercial density. In times of high traffic in the store, playing on material elements is appropriate, while in times of low traffic, sales staff can take over and move from expressing social distinction to enacting a more inclusive role that fits with the democratization of luxury (Cristini et al., 2017) and the evolution of luxury customer profiles (Banister et al., 2020). Integrating hints of homeyness may constitute an opportunity for luxury brands to dust off the concept of luxury in exclusive brand stores and move to a more unconventional luxury (Thomsen et al., 2020), as is already the case through pop-up stores, shop in shops, web stores, or other retail environments. For example, Louis Vuitton welcomes special customers in its mansion near Paris; called the "family home," this place is also accessible to everyone during Open Days, similar to many other private castles and buildings.

Finally, as the democratization of luxury develops, brand stores could also benefit from playing with the public versus private (and exclusive) aspects of both homeyness and luxury. Overplaying or downplaying domestic meanings associated with social stratification can help regulate the flux of consumers entering the store, as is the case with music tempo inside the store (Rieunier, 2000). During peak days, stores could overplay the exclusiveness of the place reserved for core members; during off-peak days, stores could downplay exclusiveness in store access and overplay intimacy, authenticity, and highly qualitative social interaction inside the store, thus favoring attachment to the place (Debenedetti et al., 2014). 


\subsection{Limitations and future research avenues}

The exploratory nature of this research, mainly based on store observations, has several limitations. First, the way managers make sense of and use (or do not use) the domestic cues available in their store is missing. Thus, future research that examines the extent to which sales managers and designers consider homeyness a resource and use it in their brand strategy would be insightful. Second, how homeyness is implemented often depends on the cultural context in which the store is embedded, but this research only observes luxury stores in one city. Thus, understanding how domestic meanings are crafted in countries where being at home entails different practices and attitudes would be fruitful.

Third, in contrast with research on domestic meanings in commercial environments (e.g., Debenedetti et al., 2014; Rosenbaum, 2006), this study takes the retailer perspective and therefore is limited to sense-giving aspects of homeyness. In line with Bäckström and Johansson (2006), who emphasize discrepancies between consumers' preferences and retailers' decisions to implement strong in-store experiences, an examination of how consumers make sense of domestic meanings in high-end commercial environments would help fully understand homeyness in a luxury context from a double-sided perspective. That is, measuring the impact of consumers' homeyness on relational variables that have previously been used in the context of mundane commercial places (e.g., Debenedetti et al., 2014; Rosenbaum, 2006) and determining which aspects of luxury (interpersonal vs. personal) have the greater impact on consumers' attitudes and behaviors would shed more light on what homeyness in luxury retail is and how it intersects with concurrent meanings, such as aesthetics (Joy et al., 2014) and creativity (Dion \& Arnould, 2011).

Finally, this research suggests that domestic, creative, and aesthetic meanings are intertwined. However, how they combine and the tensions that may arise in jointly managing 
them or aligning them with market constraints remain unclear. A broader perspective on how luxury brands stage meanings in their stores would advance understanding of the relationship between market and non-market meanings in the luxury world.

\section{Conclusion}

More than 20 years ago, Rybczynski (1986) argued that home was the central theme of the commercial space, with the public place taking on the attributes of the private place, thus bringing the commercial space closer to clients. Retail research has more recently shown that customers of local independent stores often feel at home because of the specific form of informal and friendly social interactions created (Debenedetti et al., 2014; Rosenbaum, 2006). This research shows that (1) luxury stores are also imbued with domestic meanings, (2) homeyness is contingent on and therefore conveyed through specific domestic cues consistent with the interpersonal and personal values of luxury, and (3) domestic meanings constitute an important but under-developed aspect of luxury retail (similar to aesthetics, creativity, and spirituality). As Bain \& Company (2018) or Fashion Network (2017) report, consumers expect traditional luxury stores to support the evolution of luxury. The current research shows that though they can sometimes be under- or misused by luxury stores, home-like cues constitute an opportunity to enrich the discourse of luxury houses. Highlighting the notion of home does not contradict the creative, historical, or sacred aspect of luxury brands. On the contrary, homeyness allows brands to humanize themselves by employing already-existing socio-material elements of their boutique network. This is especially important for millennials, who, according to specialized press (e.g., Gustafson, 2015), do not necessarily recognize themselves in the range of traditional values used by luxury brands but instead seek other values and types of interaction. If retail luxury "is producer rather than consumer 
oriented" (Dion \& Arnould, 2011, p. 502), luxury houses can combine personal pleasure not only with awe but also with homey environments. 


\section{References}

Alexander, B. (2019). Commercial, social and experiential convergence: Fashion's third places. Journal of Services Marketing, 33(3), 257-272.

Annuaire-Almanach du Commerce de Didot-Bottin (1888). $91^{\text {ème }}$ année, 525.

Arsel Z., \& Bean, J. (2013). Taste regimes and market-mediated practice. Journal of Consumer Research, 39(3), 899-917.

Bäckström, K., \& Johansson, U. (2006). Creating and consuming experiences in retail store environments: Comparing retailer and consumer perspectives. Journal of Retailing and Consumer Services, 13(6), 417-430.

Bain \& Company (2018). Luxury goods worldwide market study. Fall-Winter 2017. https://www.bain.com/insights/luxury-goods-worldwide-market-study-fall-winter$2017 /$.

Banister, E., Roper, S., \& Potavanich, T. (2020). Consumers' practices of everyday luxury. Journal of Business Research, 116, 458-66.

Bardhi, F., \& Askegaard, S. (2009). Home away from home. Home-as-order and dwelling in mobility. In Sherry, J \& Fischer E. (Eds.), Exploration in consumer culture theory (pp. 83-97). Routledge.

Baron, K. (2015). The secrets to luxury online for millennials. Luxury Society, 16(September). http://luxurysociety.com/articles/2015/09/the-secrets-to-luxury- online-for-millennials.

Bastien, V., \& Kapferer, J. L. (2012). Luxe oblige. Eyrolles.

Beverland, M. (2005), Crafting brand authenticity: The case of luxury wines. Journal of Management Studies, 42, 1003-1029.

Blunt, A. (2005). Cultural geography: cultural geographies of home. Progress in Human Geography, 29(4), 505-515. 
Boltanski, L., \& Thévenot, L. (2006). On justification: Economies of worth, Princeton studies in cultural sociology, trans. C. Porter. Princeton University Press.

Bonnemaizon, A., Debenedetti, A., \& Mérigot, P. (2016). La participation du client au sein d'un environnement commercial: Exploration des dispositifs et de l'initiative client dans un lieu attachant. Décisions Marketing, 82(Avril-Juin), 91-108.

Borghini, S., Diamond, N., Kozinets, R. V., McGrath, M. A., Muniz Jr., A. M., \& Sherry Jr., J. F. (2009). Why are themed brandstores so powerful? Retail brand ideology at American Girl Place. Journal of Retailing, 85(3), 363-375.

Bourdieu, P. (1979). La distinction. Critique sociale du jugement. Les Éditions de Minuit.

Cervellon, M. C., \& Coudriet, R. (2013). Brand social power in luxury retail: Manifestations of brand dominance over clients in the store. International Journal of Retail \& Distribution Management, 41(11/12), 869-884.

Chandon, J-L., Laurent, G., \& Valette-Florence, P. (2016). Pursuing the concept of luxury: Introduction to the JBR Special Issue on "Luxury Marketing from Tradition to Innovation." Journal of Business Research, 69, 299-303.

Charleston, S. (2009). The English football ground as a representation of home. Journal of Environmental Psychology, 29, 144-150.

Cristini, H., Kauppinen-Räisänen, H., Barthod-Prothade, M., \& Woodside, A. (2017). Toward a general theory of luxury: Advancing from workbench definitions and theoretical transformations. Journal of Business Research, 70, 101-107.

de Lassus, C., \& Freire, N. A. (2014). Access to the luxury brand myth in pop-up stores: A netnographic and semiotic analysis. Journal of Retailing \& Consumer Services, 21, $61-68$.

Debenedetti, A., Oppewal, H., \& Arsel, Z. (2014). Place attachment in commercial settings: A gift economy perspective. Journal of Consumer Research, 40(5), 904-923. 
Dion, D., \& Arnould, E. J. (2011). Retail luxury strategy: Assembling charisma through art and magic. Journal of Retailing, 87(4), 502-520.

Dion, D., \& Borraz, S. (2015). Managing heritage brands: A study of the sacralization of heritage stores in the luxury industry. Journal of Retailing and Consumer Services, 22(January), 77-84.

Dion D., \& Borraz, S. (2017). Managing status: How luxury brands shape class subjectivities in the service encounter. Journal of Marketing, 81(5), 67-85.

Fashion Network (2017. April 10). Les achats aspirationnels reculent face à la notion de confort. https://fr.fashionnetwork.com/news/Luxe-les-achats-aspirationnels-reculentface-a-la-notion-de-confort, 815186. html.

Glaser, B., \& Strauss, A. (1967). The discovery of grounded theory: Strategies for qualitative research. Aldine.

Gustafson, K. (2015, February 18). Millennials redefine luxury. And the stakes are high, CNBC Retail. https://www.cnbc.com/2015/02/18/-redefine-luxury-and-the-stakes-arehigh.html.

Joy, A., Wang, J. J., Chan, T. S., Sherry Jr., J. F., \& Cui G. (2014). M(Art)worlds: Consumer perceptions of how luxury brand stores become art institutions. Journal of Retailing, $90(3), 347-364$.

Kapferer, J. L. (2014). The artification of luxury: From artisans to artists. Business Horizons, $57,371-380$.

Kefi, H., \& Maar, D. (2018). The power of lurking: Assessing the online of luxury brand fan page followers. Journal of Business Research, 117(9), 579-586.

Kim, S., Park, G., Lee, Y., \& Choi, S. (2016). Customer emotions and their triggers in luxury retail: Understanding the effects of customer emotions before and after entering a luxury shop. Journal of Business Research, 69(12), 5809-5818. 
Klein, J. F., Falk, T., Esch, F.-R., \& Gloukhovtsev, A. (2016). Linking pop-up brand stores to brand experience and word of mouth: The case of luxury retail. Journal of Business Research, 69, 5761-5757.

Ko, E., Costello, J. P., \& Taylor, C.R. (2019). What is a luxury brand? A new definition and review of the literature. Journal of Business Research, 99, 405-413.

Ko, E., Phau, I., \& Aiello, G. (2016). Luxury brand strategies and customer experiences: Contributions to theory and practice. Journal of Business Research, 69(12), 57495752.

Korosec-Serfaty, P. (1984). The home from attic to cellar. Journal of Environmental Psychology, 4(4), 303-321.

Lunardo, R., \& Mouangue, E. (2019). Getting over discomfort in luxury brand stores: How pop-up stores affect perceptions of luxury, embarrassment, and store evaluations. Journal of Retailing \& Consumer Services, 49, 77-85.

LVMH (2018). Annual report. https://www.lvmh.fr/rapportannuelinteractif2018/fr/index.html\#/page/0.

Manzo, L. (2003). Beyond house and haven: Toward a provisioning of emotional relationship with places. Journal of Environmental Psychology, 23, 47-61.

McCracken, G. (1989). "Homeyness," a cultural account of one constellation of consumer goods and meanings. In E. C. Hirschman (Ed.), Interpretive consumer research (pp. 168-183). Association for Consumer Research.

Moore, C. M., Doherty, A. M., \& Doyle, S. A. (2010). Flagship stores as a market entry method: the perspective of luxury fashion retailing. European Journal of Marketing, 44(1/2), 139-161.

Napoli, J., Dickinson, S. J., Beverland, M. B., \& Farrelly, F. (2014). Measuring consumerbased brand authenticity. Journal of Business Research, 67(6), 1090-1098. 
Oldenburg, R. (1999). The great good place: Cafés, coffee shops, community centers, beauty parlors, general stores, bars, hangouts and how they get you through the day. Paragon House.

Oyedele, A., \& Simpson, P. (2018). Emerging adulthood, sharing utilities and intention to use sharing services. Journal of Services Marketing, 32(2), 161-174.

Pine, J. B., \& Gilmore, J. H. (1999). The experience economy: Work is theatre and every business a stage. Harvard Business School Press.

Price, L. L., \& Arnould, E. J. (1999). Commercial friendships: Service provider-client relationships in context. Journal of Marketing, 63(4), 38-56.

Rieunier, S. (2000). L'influence de la musique d'ambiance sur le comportement des consommateurs sur le lieu de vente. Doctoral dissertation, Université Paris-Dauphine.

Riot, E., Chamaret, C., \& Rigaud, E. (2013). Murakami on the bag: Louis Vuitton's decommoditization strategy. International Journal of Retail \& Distribution Management, 41(11/12), 919-939.

Rosenbaum, M. S. (2006). Exploring the social supportive role of third places in consumers' lives. Journal of Service Research, 9, 59-72.

Rosenbaum, M. S., Ward, J., Walker, B. A., \& Ostrom, A. L. (2007). A cup of coffee with a dash of love: An investigation of commercial social support and third-place attachment. Journal of Service Research, 10, 43-59.

Roster, C. A., Ferrari, J. R., \& Jurkat, M. P. (2016). The dark side of home: Assessing possession “clutter" on subjective well-being. Journal of Environmental Psychology, $46,32-41$.

Roux, E., Tafani, E. \& Vigneron, F. (2017). Values associated with luxury brand consumption and the role of gender. Journal of Business Research, 71, 102-113.

Rybczynski, W. (1986). Home: A short story of an idea. Viking. 
Schultz, M., Chaney, D. \& Debenedetti, A. (2016). An integrative perspective of closeness in retailing: From retailers' sense-giving to consumers' sense-making. Journal of Retailing \& Consumer Services, 32, 218-226.

Seeley, J. R., Sim R. A., \& Loosley, E. W. (1956). Crestwood Heights: A study of the culture of suburban life. University of Toronto Press.

Seo, Y., \& Buchanan-Oliver, M. (2019). Constructing a typology of luxury brand consumption practices. Journal of Business Research, 99, 414-421.

Sixsmith, J. (1986). The meaning of home: An exploratory study of environmental experience. Journal of Environmental Psychology, 6, 281-298.

Smith, S. G. (1994). The essential qualities of a home. Journal of Environmental Psychology, $14,31-46$.

Thomsen, T. U., Holmqvist, J., von Wallpach, S., Hemetsberger, A., \& Belk, R. W. (2020). Conceptualizing unconventional luxury. Journal of Business Research, 116, 441-445.

Ulver-Sneistrup, S., \& Johansson, U. (2012). Exploring the everyday branded retail experience: The consumer quest for "homeyness" in branded grocery stores. In D. W. Dahl, G. V. Johar, \& S. M. J. van Osselaer (Eds.), Advances in consumer research (Vol. 38, pp. 309-315). Association for Consumer Research.

van der Klis, M., \& Karsten L. (2009). Commuting partners, dual residences and the meaning of home. Journal of Environmental Psychology, 29, 235-245.

Vigneron, F. \& Johnson, L.W. (1999). A review and a conceptual framework of prestigeseeking consumer behavior. Academy of Marketing Science Review, 1(1), 1-15.

Vukadin, A., Lemoine, J. F., \& Badot, O. (2016). Opportunities and risks of combining shopping experience and artistic elements in the same store: A contribution to the magical functions of the point of sale. Journal of Marketing Management, 32(9/10), 944-964. 
Ward, M.K., \& Dahl, D.W. (2014). Should the devil sell Prada? Retail rejection increases aspiring consumers' desire for the brand. Journal of Consumer Research, 41(3), 590609.

Watson, T. J. (2011). Ethnography, reality, and truth: The vital need for studies of "how things work" in organizations and management. Journal of Management Studies, $48(1), 202-217$.

Welté, J. B., \& Ochs, L. (2015). L'appropriation des clients dans les boutiques de marque de luxe: Proposition d'une typologie. Décisions Marketing, 80, 53-68. 


\section{Appendix 1}

Final list of stores.

\begin{tabular}{|c|c|c|c|}
\hline Brand & Location (Paris) & $\begin{array}{l}\text { Number } \\
\text { of visits }\end{array}$ & $\begin{array}{l}\text { Informal interaction } \\
\text { with personnel }\end{array}$ \\
\hline Alexander Mc Queen & Rue Saint Honoré & 1 & \\
\hline Antik Batik & Rue des Minimes & 1 & $\mathrm{X}$ \\
\hline Baccarat & Place des États-Unis & 2 & \\
\hline Balenciaga & Rue Saint Honoré & 2 & \\
\hline Balmain & Rue Saint Honoré & 1 & $\mathrm{X}$ \\
\hline Berluti & Rue de Sèvres & 1 & \\
\hline Bonpoint & Rue de Tournon & 1 & \\
\hline Boucheron & Place Vendôme & 2 & $\mathrm{X}$ \\
\hline Breitling & Rue de la Paix & 1 & $\mathrm{X}$ \\
\hline Bücherer & Boulevard des Capucines & 2 & \\
\hline Bulgari & $\begin{array}{l}\text { Avenue George V } \\
\text { Place Vendôme }\end{array}$ & $\begin{array}{l}1 \\
1\end{array}$ & \\
\hline Cartier & $\begin{array}{l}\text { Avenue des Champs Élysées } \\
\text { Rue de la Paix }\end{array}$ & $\begin{array}{l}3 \\
2\end{array}$ & \\
\hline Chanel & $\begin{array}{l}\text { Rue des Francs Bourgeois } \\
\text { Avenue Montaigne } \\
\text { Place Vendôme } \\
\text { Rue Cambon } \\
\text { Joaillerie avenue Montaigne }\end{array}$ & $\begin{array}{l}1 \\
2 \\
3 \\
1 \\
1\end{array}$ & $\mathrm{X}$ \\
\hline Chloé & $\begin{array}{l}\text { Avenue Montaigne } \\
\text { Rue Saint Honoré }\end{array}$ & $\begin{array}{l}1 \\
1\end{array}$ & \\
\hline Chopard & Rue Saint Honoré & 1 & \\
\hline Christofle & Le Printemps Dpt Store & 2 & \\
\hline Coach & Rue Saint Honoré & 1 & \\
\hline Dior & $\begin{array}{l}\text { Avenue des Champs Élysées } \\
\text { Avenue Montaigne }\end{array}$ & $\begin{array}{l}1 \\
1\end{array}$ & $\mathrm{X}$ \\
\hline Ferragamo & $\begin{array}{l}\text { Avenue Montaigne } \\
\text { Rue de Grenelle }\end{array}$ & $\begin{array}{l}1 \\
1\end{array}$ & $\mathrm{X}$ \\
\hline Goyard & $\begin{array}{l}\text { Rue Saint Honoré } 233 \\
\text { Rue Saint Honoré } 352\end{array}$ & $\begin{array}{l}1 \\
1\end{array}$ & $\mathrm{X}$ \\
\hline Hermès & $\begin{array}{l}\text { Avenue George V } \\
\text { Rue de Sèvres }\end{array}$ & $\begin{array}{l}2 \\
6\end{array}$ & \\
\hline
\end{tabular}




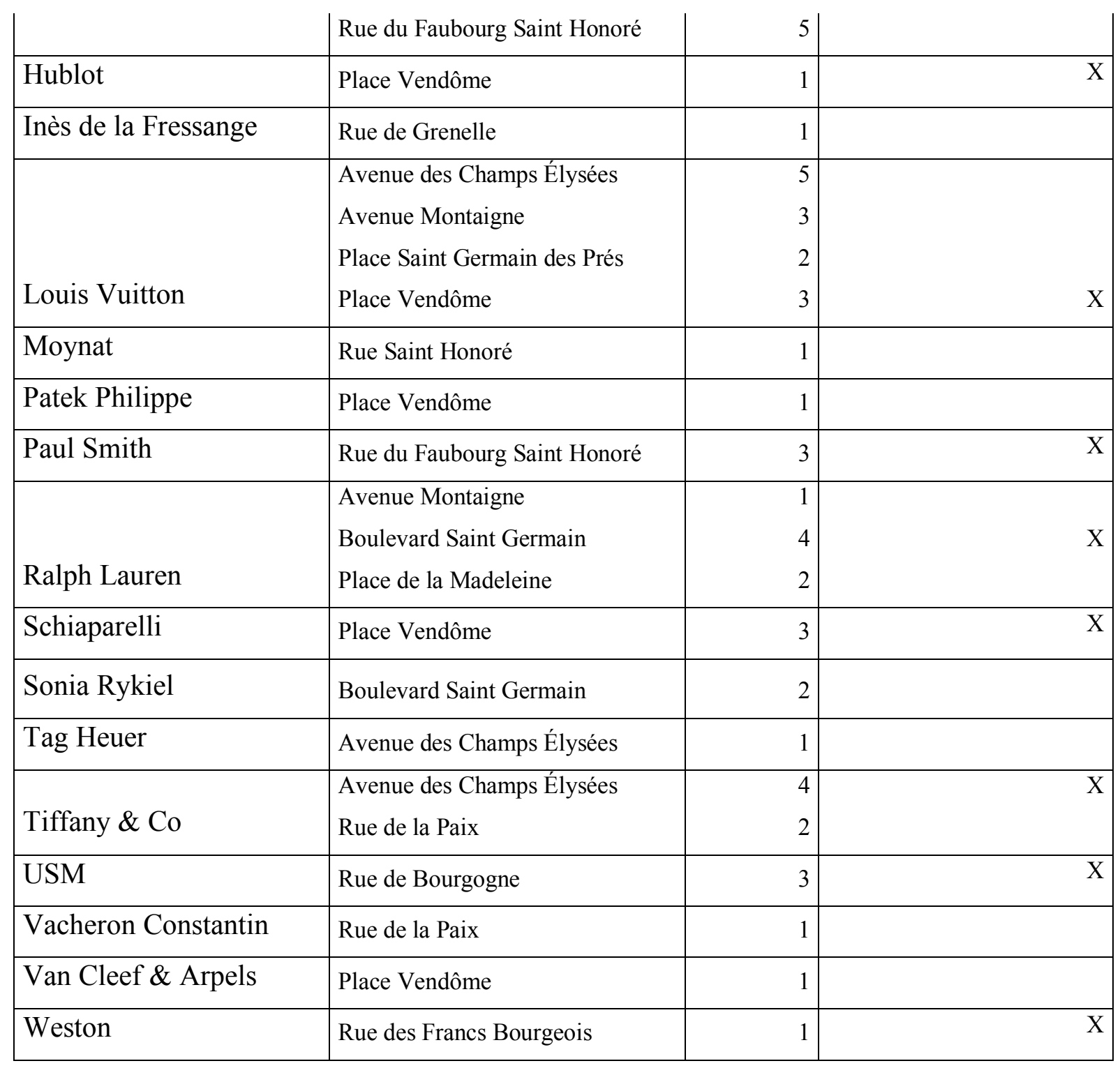

